\title{
The Effect of Inflation and Corporate Social Responsibility on Share Returns with Profitability as Intervening Variables in the Mining Sector: 2017-2019 Period
}

Verry Allan Dwi Prastyo*, Slamet Riyadi and Sunu Priyawan

Faculty of Economics and Business, University of 17 August 1945 Surabaya, Indonesia

\begin{tabular}{|c|c|}
\hline ARTICLE INFO & ABSTRACT \\
\hline $\begin{array}{l}\text { Keywords: } \\
\text { Stock Return } \\
\text { Profitability } \\
\text { Corporate Social } \\
\quad \text { Responsibility } \\
\text { Inflation } \\
\text { Structural Equation } \\
\text { Modeling Partial Least } \\
\text { Square (SEMPLS) }\end{array}$ & $\begin{array}{l}\text { This study aims to prove the effect of inflation and corporate social } \\
\text { responsibility on stock returns with profitability as an intervening } \\
\text { variable in mining listed on the Indonesia Stock Exchange. The } \\
\text { population of this study is } 47 \text { mining sector companies listed on the } \\
\text { Indonesia Stock Exchange (BEI). The sampling technique uses a } \\
\text { purposive sampling method which has certain criteria in taking } \\
\text { samples that have an annual financial report } 2017-2019 \text {, in order to } \\
\text { obtain } 22 \text { companies. mining sector is listed on the Indonesia Stock } \\
\text { Exchange (IDX). The method of this research uses analysis of } \\
\text { Structural Equation Modeling (SEM) based on variance, namely } \\
\text { Partial Least Square (PLS). SEM with variance-based PLS so that it } \\
\text { can handle two conditions, namely conditions with undetermined } \\
\text { factors and conditions where the solution cannot be accepted. This } \\
\text { study uses a computer program from smart PLS } 3.2 \text { which is to } \\
\text { determine which variables are significant to stock returns in mining } \\
\text { listed on the Indonesia Stock Exchange for the 2017-2019 period. } \\
\text { The results of this research show that: (1) inflation has a significant } \\
\text { effect to stock returns; (2) inflation has a significant impact on } \\
\text { profitability; (3) corporate social responsibility has a major impact on } \\
\text { stock returns; (4) corporate social responsibility has a significant } \\
\text { impact on profitability; (5) profitability has a significant impact on } \\
\text { stock returns. }\end{array}$ \\
\hline
\end{tabular}

\section{Introduction}

In general, the capital market has an important role in the progress of a country's economy, because companies can get funds to support their operations, one of which is through the capital market facilities. Meanwhile, for shareholders or investors, both individuals and companies, the capital market can be a means of investing their funds to get benefits in the form of dividends and capital gains. Because in general, companies that sell securities (stocks or bonds)

* Corresponding author E-mail address: verryad@yahoo.com

Cite this article as:

Prastyo, V. A. D., Riyadi, S., \& Priyawan, S. (2021). The Effect of Inflation and Corporate Social Responsibility on Share Returns with Profitability as Intervening Variables in the Mining Sector: 2017-2019 Period. International Journal of Applied Research in Management and Economics, 4(1), 13-29. https://doi.org/10.33422/ijarme.v4i1.472

(C) The Author(s). 2021 Open Access. This article is distributed under the terms of the Creative Commons Attribution 4.0 International License, which permits unrestricted use, distribution, and redistribution in any medium, provided that the original author(s) and source are credited 
to the capital market are companies that already have a good and reliable business reputation, so that the shares issued will be sold and traded on the stock exchange.

According to the Capital Market Law of the Republic of Indonesia Number 8 of 1995 Article 1 point 13 states that "The capital market is an activity that is concerned with public offerings and trading in securities, public companies related to the securities they issue, as well as institutions and potentials related to securities. Shares are securities as evidence of participation or ownership of individuals or institutions in a company (Ang, 1997). Meanwhile, according to Suad Husnan (2005: 29) shares are proof of taking part or participating in a public company. According to Jogiyanto (2010: 205), Stock Return is the value obtained as a result of investing activities. The expected return is in the form of dividends for stock investment and interest income for investment in debt securities. Return is the main objective of investors to get results from the investment made by investors. With a high enough stock return, it will be more attractive for investors to buy these shares. Therefore, to be able to find out how much return an investor will get, potential investors and investors need to make predictions in order to find out how much return they will get. According to Jogiyanto (2010: 205) there are 2 types of returns, namely: (1) Expected Return. Expected return is the return expected in the future by investors. Contrary to the realized Return which Already happened, not yet anticipated return; (2) Realized Return Realized return is the return that came about. Realized returns are based upon historical evidence, estimated. Realizing returns is important since it is seen as an indicator of the success of the business.

This historical return is also useful as a basis for determining the expected return and risk in the future. There are 2 types of stock return components, namely capital gains (profit from the difference in stock prices) and current income. Capital benefit is the reward earned as a result of the disparity in value between the sale price and the buying price of the shares of the investment instrument, which means that the investment instrument must be traded on the market. For trading, there will be adjustments in the valuation of the investment instrument resulting in capital gains (Ang, 1997). The second component of Stock Return is present profits, which is the benefit received by annual transfers, such as payment of interest on loans, dividends, interest on shares, and so on. Present income is considered current income, since the earnings earned are typically in the form of currency or cash equivalents, meaning that they can be cashed out easily. Benefit in the form of currency, such as interest, current accounts and cash dividends. In the meantime, gains in the form of cash substitutes such as incentive shares and bond dividends (Ang, 1997).

In the capital market, profits from shares can be related to stock returns. Because stock returns are the main goal of shareholders or investors, therefore companies must provide a sense of security and trust to investors by providing optimal returns from the investments in their company. Determination of stock returns can be seen from the performance of the company that issued the shares from the stock price at the end of year to year. Investors expect maximum returns. The hope of obtaining the maximum return will be pursued so that it can be realized by conducting analysis and taking actions related to investing in its shares. In stock returns, inflation also influences investors to invest in a company.

Bramantyo (2006: 2) notes that in order to evaluate the stock return, there are 2 (two) forms of analysis, namely fundamental information and technical information. Fundamental data, including dividends and the revenue growth rate of the company, is collected from within the 
company, while technical information, such as economic, political and financial information, is obtained outside the company. Financial information in the form of accounting information summarized in the financial statements and non-financial information in the form of nonaccounting information not summarized in the financial reports are the information derived from the internal situation of the business used. As a factor used by investors to forecast stock returns, fundamental and technical knowledge can be used. If the company's outlook is very strong and healthy, it is expected that the company's stock return will also increase.

Investing by calculating the Stock Return is not enough for investors, because the risks of investing also need to be considered and considered by investors. Because between risk and return are two things that cannot be separated. Return and risk Have a positive relationship, the greater the risk that must be borne, the higher the return that must be compensated.

Danger is also correlated with the variance or deviation from the obtained and anticipated result. In order to calculate the risk, the method widely used is the standard deviation, which measures the absolute deviation of the values that occurred with the expected value.

Shares are one of the securities traded on the IDX in addition to bonds and certificates. Shares are a deposit of an amount of money from the owner as proof of ownership submitted to the parties who manage the paid-in capital, and have rights according to the type of shares owned. Meanwhile, according to Simamora (2000: 408) defines shares as a unit of ownership in a company. Shares are the rights of part of a company, for example shares in a Limited Liability Company (PT), or a proof of participation or participation in the capital of a company. Shareholders of a company also own a portion of the company. Shares are owned by those who have bought them, that is, those who have submitted a certain amount of funds or money to the company so that the company can work, as proof of ownership is issued a share certificate. They are then called "Shareholders", in everyday speech, often the term "letter" in share certificates is forgotten, and people call it just shares. Shares are proof of equity participation from investors against companies selling shares or issuing shares. In stock returns, inflation also affects stock development.

Inflation is a general increase in prices, or it can also be said to be a decrease in the purchasing power of money. The higher the price increase, the lower the value of money. An increase in the price of certain goods or a price increase due to a failed harvest, for example, does not include inflation. The most widely used measure of inflation is the "consumer price index" or "cost of living index". This index is based on the price of a package of goods selected and represents the pattern of consumer spending.

Kuncoro (1998: 46) states that the tendency of prices to increase is general and continuous. An increase in the price of one or two goods cannot be called inflation, unless the increase extends or results in an increase in other goods. According to Boediono (1994: 155) inflation is the tendency of prices to increase in general and continuously. An increase in the price of one or two goods is not called inflation. The conditions for a continuous increasing trend also need to be underlined. An increase in prices due to, for example, seasonality, before holidays, disasters, etc., which are only temporary in nature, are not called inflation.

Mining companies are generally companies that have the potential to cause pollution and disturbance to the community. The forms of pollution that are often caused by the operational activities of mining companies include damage to soil structure, damage to irrigation channels, the emergence of chemical waste, decreased soil fertility and so on. In this connection mining 
companies must have a program and allocate a social responsibility budget (Corporate Social Responsibility) to reduce the impact of pollution and provide compensation for losses suffered by the surrounding community.

Corporate social responsibility is the concept for a company's environmental and societal responsibilities (CSR). Corporate social responsibility carried out by the company aims to balance and restore what the company has done that has a negative impact on the environment and society. In addition, through the CSR program, the company participates in environmental conservation efforts for the sake of long-term maintenance of the quality of human life. Companies who exercise corporate responsibility are supposed to do more than simply produce short-term profits; they are often expected to enhance the health and standard of living of their communities and the community. (Priyanka, 2013).

Angelia \& Suryaningsih (2015) companies that disclose CSR in their annual reports will receive awards from the government and environmental organizations, because the CSR report shows the quality of the company and the attitude of corporate responsibility for its production process and the public will assess the safety and health of consumers in using products from the company. This can increase the confidence and level of sales of the company's products. In addition, the existence of a CSR report can be used as one of the competitive advantages of a company because it provides information about financial aspects as well as social and environmental aspects, including the company's strategy and operations, which are one of the factors that bring profit to the company so that it can be used as input in decision making by the company. investors (Putra, 2015).

With the passing of Law No. 40 of 2007, Article 74 on limited liability companies, understanding of environmental conservation has begun to rise in Indonesia. which states that: (1) companies carrying out their commercial operations in the sectors and/or linked to natural resources are obliged to carry out social and environmental obligations; (2) social and environmental responsibilities as alluded to in Law. In the first paragraph, there is a business duty that is budgeted and measured as a company obligation. corporate cost which in practice is carried out with due regard to fairness and reasonableness, (3) The organization shall not comply with the responsibilities referred to in paragraph (1) and shall be subject to fines in compliance with the regulatory requirements (4) Further provisions on social and environmental responsibility shall be governed by the Government Regulations.

The case that occurred at the world's largest mining company Grasberg in West Papua which was operated by Freeport, where its existence did not make the surrounding community prosperous, even the environment where they lived was contaminated with hazardous waste, causing various diseases, in addition to the case that occurred in Buyat Bay which conducted by the Newmont company where arsenic contamination in drinking water there causes high mortality rates among children and women. This case has opened the eyes of the general public and companies about the importance of corporate social responsibility (Setyorini \& Ishak, 2012). Corporate social responsibility needs to be disclosed because CSR is a long-term growth plan for the firm and is expected to have a social commitment to interested parties and not only to owners or shareholders. Disclosure of social responsibility is a process of communicating to interested groups and to society regarding the social and environmental impacts that have been generated from the organization's economic activities. 
According to A. Kusumah (2017), corporate social responsibility disclosure (CSRD) can help users of financial statements (stakeholders) as consideration for decision making, because decision making is not always only seen from the financial aspect but also needs to consider non-financial aspects. Stakeholder awareness of CSR activities is getting higher, making the disclosure of social and environmental reports in financial reports can provide a good image so that investors are interested in investing.

When an investment decision is an important consideration for investors, it will significantly affect stock returns and company profitability. The CSR report is used for investors to assess the development of mining companies. The development of CSR can be measured through analysis of data and ratio analysis contained in annual financial reports. In this case CSR can be used by investors to find out the value of the ROA and ROE indicators.

The stock return according to Arista, Desy, \& Astohar (2012) is the selling price above the purchase price of the shares. The higher the selling price of the shares above the purchase price, the higher the return earned by investors. If an investor wants a high return, the investor must bear a higher risk, and vice versa if an investor wants a low return, the risk to be borne is also low. Research conducted by Priyanka (2013) reveals that CSR disclosure does not have a positive effect on returns on equity or ROE and on returns on assets or ROA. However, CSR disclosure has a positive effect on earnings per share or EPS and net profit margin (NPM). Research conducted by Khairudin \& Dewi, E. (2015) suggests that CSR has a positive effect on profitability, which is proxied by gross profit margin (GPM), return on assets (ROA), and return on equity (ROE). M. Wardani's research (2015) states that CSR has no effect on return on equity (ROE), CSR has no positive effect on return on assets (ROA), and CSR has no positive effect on earnings per share (EPS). Research conducted by Hardaningtyas \& Siswoyo (2016) reveals that CSR has a positive effect on the stock returns of companies listed on LQ45 in 2015 .

The mining sector is one of the mainstay economic subsectors in Indonesia, especially from the gas and oil sub-sector. However, until now, the contribution of the mining sub-sector to national income is still low. This requires encouragement to increase investment in the mining sector and to facilitate the licensing process.

Based on data released by the Indonesia Stock Exchange (IDX) at the beginning of 2020, it is stated that the mining sector has an effect on the Composite Stock Price Index (IHSG). For 2019 the mining sector became one of the triggers for losses in the Composite Stock Price Index (IHSG) which grew negatively at $12.83 \%$.

Behind all of that, there is actually a huge opportunity for Indonesia because mining materials will always be needed by humans, as well as Indonesia's very high geological potential and of course soaring mineral demand.

In relation to the constraints and opportunities faced by the mining sector, there are several efforts that can be made such as, the need to accelerate the ratification of the Mineral and Coal Bill which regulates the use of minerals and coal, synchronization and harmonization of policies for all legal products relating to the mining sector which are cross-sectoral both central and regions, encouraging increased local expenditure by increasing the use of products from domestic supporting industries, encouraging the growth of the domestic mineral product processing industry so as to increase the added value of national mineral and coal products and the one-door policy in licensing for mining sector investment. 
In this regard, mining is one of the reasons for investors to enter, because many of these have influenced the price increase in the mining sector. What is done by the mining sector to influence the level of share prices is the existence of Corporate Social Responsibility (CSR) which can cause an increase or decrease in stock index prices, macroeconomics is also one of the causes of an increase in stock prices, and investment decision also affects an investor to invest a capital into the mining sector to influence the increase in share prices of the mining sector.

Companies must have working capital so that the company's operations become smoother and the ultimate goal of the company to generate maximum profit will be achieved (Ambarwati, 2010: 112). Own working capital according to Fahmi (2016: 100) is a company's investment in short-term assets - cash, securities, inventories and receivables. According to Riyanto (2010: 112) companies must have primary working capital and normal working capital so that the company can continue to operate in normal capacity to meet consumer needs in the form of finished goods. In their research, Sufiana and Purwanti (2012) state that if the company finds excess working capital it will cause a lot of unemployed funds, so that it can reduce profitability and stock returns if the company lacks working capital, it will hinder the company's operational activities.

The growth in stock returns that has been increasing since 2019 can be said to have helped the rate of stock returns that were obtained.

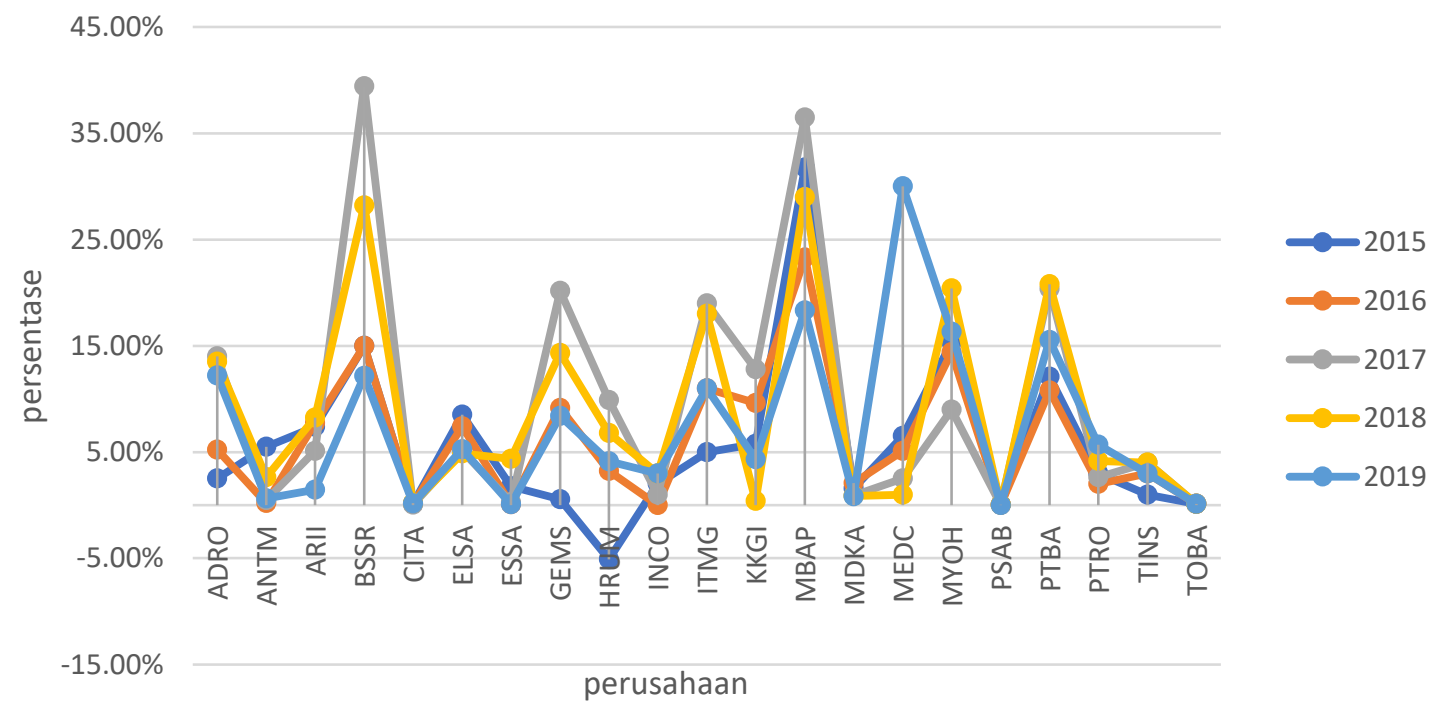

Figure 1. Graph of Go Public Mining Company ROA Development

Source: Secondary Data Processed, 2020

In the graph above, it explains that from the last few years there has been a decline in prices in the mining sector, such as falling prices from coal mining throughout 2019. From this graph throughout 2019 mining companies have experienced a decline such as PT. Adaro Energy Tbk (ADRO) recorded a yield of $12.20 \%$. PT. Aneka Tambang Tbk (ANTM) recorded a yield of $0.61 \%$. PT Atlas Resources Tbk (ARII) recorded a return on assets of $1.46 \%$. PT Baramulti Suksessarana Tbk (BSSR) recorded a yield of 12.5\%. PT Cita Mineral Investindo Tbk (CITA) recorded a yield of $0.17 \%$. PT Elnusa Tbk (ELSA) recorded a yield of 5.24\%, from the company PT Elnusa Tbk experienced an increase in yield from 2018 to 2019 of $0.4 \%$. PT Surya 
Esa Perkasa Tbk (ESSA) recorded a yield of 0.07\%. PT. Golden Energy Mines Tbk (GEMS) recorded a yield of $8,4 \%$. PT Harum Energy Tbk (HRUM) recorded a yield of $4.1 \%$. PT Vale Indonesia Tbk (INCO) recorded the same yield from 2018, namely 3\%, did not experience a decrease in 2018 to 2019. PT Indo Tambangraya Megah Tbk (ITMG) recorded a yield of 11\%. PT Resource Alam Indonesia Tbk (KKGI) experienced an increase from its 2018 to 2019 yield of $3.9 \%$ and recorded a yield in 2019 of $4.3 \%$. PT Mitrabara Adiperdana Tbk (MBAP) recorded a yield of $18.33 \%$. PT Merdeka Copper Gold Tbk (MDKA) recorded a yield of $0.81 \%$. PT Medco Energi Internasional Tbk (MEDC) experienced a fairly rapid increase in 2019 reaching $29 \%$ and recorded a return of $30 \%$. PT Samindo Resources Tbk (MYOH) recorded a return of $16.3 \%$. PT J Resources Asia Pasifik Tbk (PSAB) recorded a yield of $0.004 \%$. PT Bukit Asam Tbk (PTBA) recorded a return of 15.54\%. PT. Petrosea Tbk (PTRO) experienced an increase in 2019 reaching $1.5 \%$ and recorded a yield of 5.68\%. PT Timah Tbk (TINS) recorded a return of $3 \%$. PT Toba Bara Sejahtera Tbk (TOBA) recorded the same yield for 5 years, namely $0.1 \%$.

\section{Literature review and hypotheses development}

\subsection{Inflation}

Inflation is an economic condition in which prices generally experience temporary increases in prices. Inflation is an economic symptom that cannot be completely eliminated. Samuelson (2001) defines inflation as a condition in which there is an increase in the general level of prices, both goods, services and production factors. This definition indicates a state of weakening purchasing power followed by a decline in the real (intrinsic) value of a country's currency.

Based on the price data, an indexed figure is compiled. An index figure that takes into account all goods purchased by consumers at each price is called the consumer price index (CPI or consumer price index $=\mathrm{CPI}$ ). Based on the consumer price index, it can be calculated how big the rate of increase in prices in general in a certain period. Usually every month, 3 months, and 1 year. Apart from using the CPI, the inflation rate can also be calculated using the GNP or GDP deflator, which is comparing GNP or GDP measured at current prices (GNP or nominal GDP) against GNP or constant price GDP (GNP or real GDP). The formula for calculating the inflation rate is:

$$
I_{n}=\frac{I H K_{n}-I H K_{n-1}}{I H K_{n-1}} 100 \% \quad I_{n}=\frac{D f_{n}-D f_{n-1}}{D f_{n-1}} 100 \%
$$

(Source: Suriyani, 2018)

This is inflation

CPI consumer price index base year (in this case the value is 100)

The CPI-1 is the consumer price index for the following year

Dfn is the GNP or GDP deflator for the following year

Dfn-1 is the GNP or GDP deflator for the initial (previous) year.

\subsection{Corporate Social Responsibility (CSR)}

Corporate Social Responsibility (CSR) is a business operation committed not only to increasing corporate profits financially, but also to the region's socio-economic development in a holistic, institutional and sustainable manner. CSR is how a company manages a company, 
both partially and as a whole, which has a positive impact on itself and the environment (Johnson and Johnson in Hadi, 2011).

According to the Global Reporting Initiative (GRI) in Nuryaman (2013), to calculate CSR disclosure items in the company's annual report using the formula for the Corporate Social Responsibility Disclosure Index (CSRDI), as follows:

(Source: Putri, 2014)

$$
\mathrm{CSRDIj}=\frac{\sum X_{i j}}{N_{j}}
$$

CSRDIj $=$ Corporate Social Responsibility Disclosure Index

$\sum X_{i j}=$ The number of items disclosed by the company $\mathrm{j}$

$N_{j}=$ The number of items that the company should disclose $\mathrm{j}$

\subsection{Profitability}

According to Sutrisno (2009: 16) "profitability is the company's ability to generate profits with all the working capital in it. Profitability in accordance with Sofyan Syafri Harahap (2009: 304) is "Describing the company's ability to earn profits through all existing capabilities and resources such as sales activities, cash, capital, number of employees, number of company branches, and so on".

Large sales and investments are needed and affect the size of the profitability ratio, the greater the sales and investment activity, the greater the profitability ratio. In general, there are four main types of analysis used to assess that the level of profitability, namely, according to Kasmir (2008: 199).

\subsubsection{Net Profit Margin (NPM)}

"Net Profit Margin is a percentage that measures net profit per rupiah sales," says Riyanto (2013: 336). "Net Profit Margin is the percentage of net operating revenues and net sales," says Riyanto (2013: 336). The percentage used to calculate the profit margin of revenue is called net profit margin. Based on cumulative net sales, this ratio would reflect the company's net revenue.

(Source: Kasmir, 2012: 200)

$$
N P M=\frac{\text { Laba setelah pajak }}{\text { penjualan }}
$$

\subsubsection{Return On Asset (ROA)}

Return on assets by Kasmir (2012: 201) is a "ratio shows the results of the total assets used in the corporation". by Toto Prihadi (2008), ROA aims to measure the company's ability to utilize assets to earn profits and measure the total results for all creditors and shareholders as providers of sources of funds. According to Toto Prihadi (2008: 68) "Return on assets is the ratio used to measure the level of profit to assets used to generate these profits".

This percentage is expressed by the following formula:

$$
R O A=\frac{\text { Laba setelah pajak }}{\text { Total aktiva }}
$$

(Source: Fahmi, 2015: 137) 


\subsubsection{Return On Equity (ROE)}

In pursuance of Brigham \& Houston (2010), "Return on Equity, or the ratio of net profits to ordinary equity, is a statistic that calculates the rate of return on a shareholder's investment. Meanwhile, according to Tandelin, "Return on Equity" is a measure of how profitable a company is defining the level to which the investors can derive the company's potential to generate profits." According to them, Sawir (2009: 20) "Return on Equity (ROE) is a ratio that calculates how efficiently a business handles its own investments to assess the amount of return on investment made by the company's own capital owners or shareholders". This percentage is expressed by the following formula:

(Source: Fahmi, 2015: 137)

$$
R O E=\frac{\text { Laba setelah pajak }}{\text { Modal sendiri }}
$$

\subsubsection{Earning Per share (EPS)}

Earnings per share (EPS) is a statistic that represents how much rupiah each popular share earns (Syamsuddin, 2009: 66). Harahap 2008: 306 by Sofyan Syafri "Earnings Per Share (EPS) is a ratio that indicates how much the potential to produce income per share is." As a result, corporate management firms, common shareholders, and potential shareholders are all quite involved in Earnings Per Share. Earnings Per Share (EPS) is a measure of a company's performance.

(Source: Fahmi, 2015: 137)

$$
E P S=\frac{\text { Laba setelah pajak }}{\text { Jumlah lembar saham beredar }}
$$

\subsection{Return Stock}

Fahmi and Yovi (2009) state that stock returns are the benefits that companies, individuals and institutions receive from the results of their investment policies. The higher the stock return, the better the investment because it can generate profits, on the contrary, the more the stock return or even negative, the worse the investment return. Stock is showing ownership rights in the profits and assets of a company. In simple terms, investment can be defined as the activity of placing funds in one or more assets during a certain period in the hope of obtaining income or an increase in investment value. In investing, a prudent investor would weigh two factors, namely the expected return and the possibility of an alternative investment. Stock return is the level of return enjoy the contribution that investors make. Of course, without the amount of return that the fund receives, investors would not invest. In investing, Present income is the benefit received by annual transfers, such as payment of interest on deposits, interest on shares, dividends and so on. The second part of the return is capital gain, which is the benefit earned as a result of the disparity between the sale price and the selling price of the investment instrument's stock, which means that the shares must be exchanged on the market. Systematically, the calculation of stock returns according to Hartono (2013) is as follows:

$$
\mathrm{RIT}=\frac{\left(P_{t}-P_{t}-1+D_{t}\right)}{P_{t}-1}
$$

(Source: Fahmi, 2015: 137)

Information

Rit: rate0of0return0on shares in I in period $\mathrm{t}$. 
Pt: the results of the closing of shares I in period t (closing period / last)

Pt-1: the0closing0price0of0shares I0in0the0previous0period.

Dt: periodic0dividends.

\section{Research Methodology}

\subsection{Conceptual Framework}

Based on literature review, previous research and hypothesis development, the concept of this research can be formulated through the following framework:

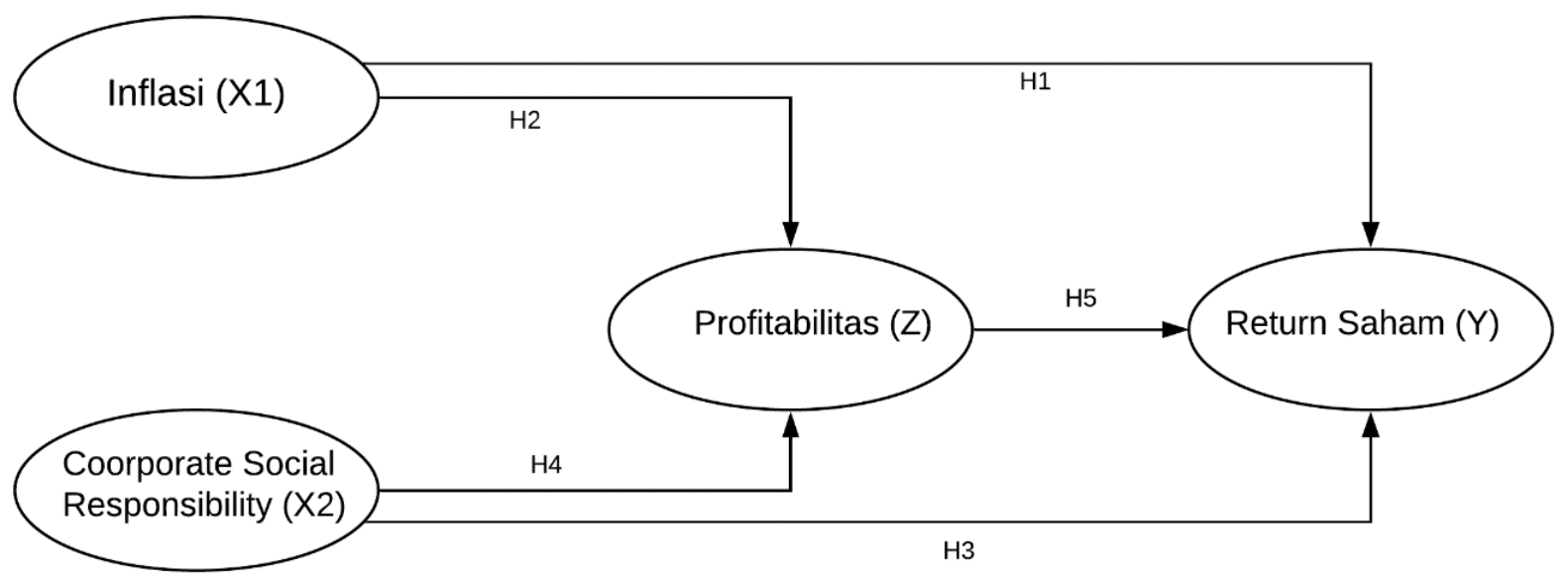

Figure 3. Conceptual Framework

\subsection{Purposive Sampling}

When utilizing the purposive sampling method, namely the sampling technique of data sources for such considerations, the sample collection, (Sugiyono, 2009).

Table 1.

Purposive Sampling Results

\begin{tabular}{lc}
\hline Sample Criteria & Total \\
\hline $\begin{array}{l}\text { For the year 2017-2019, the number of mining companies that have been } \\
\text { and are currently registered on the Indonesian Stock Exchange. }\end{array}$ & 46
\end{tabular}

\section{Deduction 1:}

Mining companies that did not have financial reports in a row during the 2017 - 2019 period

\section{Deduction 2:}

Mining companies that do not have a CSR record

\section{Deduction 3:}

There is no availability of variable data under study

\section{Results and discussions}

\subsection{Statistic analysis}

The mean, standard deviation, lowest value, and highest value are all used in descriptive statistical analysis to provide a general summary of the results. The descriptive study produced the following results: 
Table 2.

Statistics that are descriptive of nature

\begin{tabular}{ccccc}
\hline Indicator & Minimum & Maximum & Mean & Std. Deviation \\
\hline Inflation Rate & 2,720 & 3,610 & 3,153 & 0.367 \\
ROA & 0.010 & 39,410 & 9,358 & 8,728 \\
ROE & 0.190 & 55,250 & 16,553 & 13,590 \\
NPM & 0.270 & 74,050 & 13,816 & 12,766 \\
EPS & 0.000 & 477,000 & 33,338 & 94,540 \\
Economy & 0.037 & 0.130 & 0.109 & 0.023 \\
Environment & 0.000 & 0.481 & 0.165 & 0.152 \\
Social & 0.000 & 0.148 & 0.082 & 0.035 \\
\hline
\end{tabular}

\subsection{Evaluate the Outer Model}

The assessment of the measurement model, which involves construct validity and construct reliability, is a stage in assessing the validity and reliability of a construct. Each one will be clarified in turn.

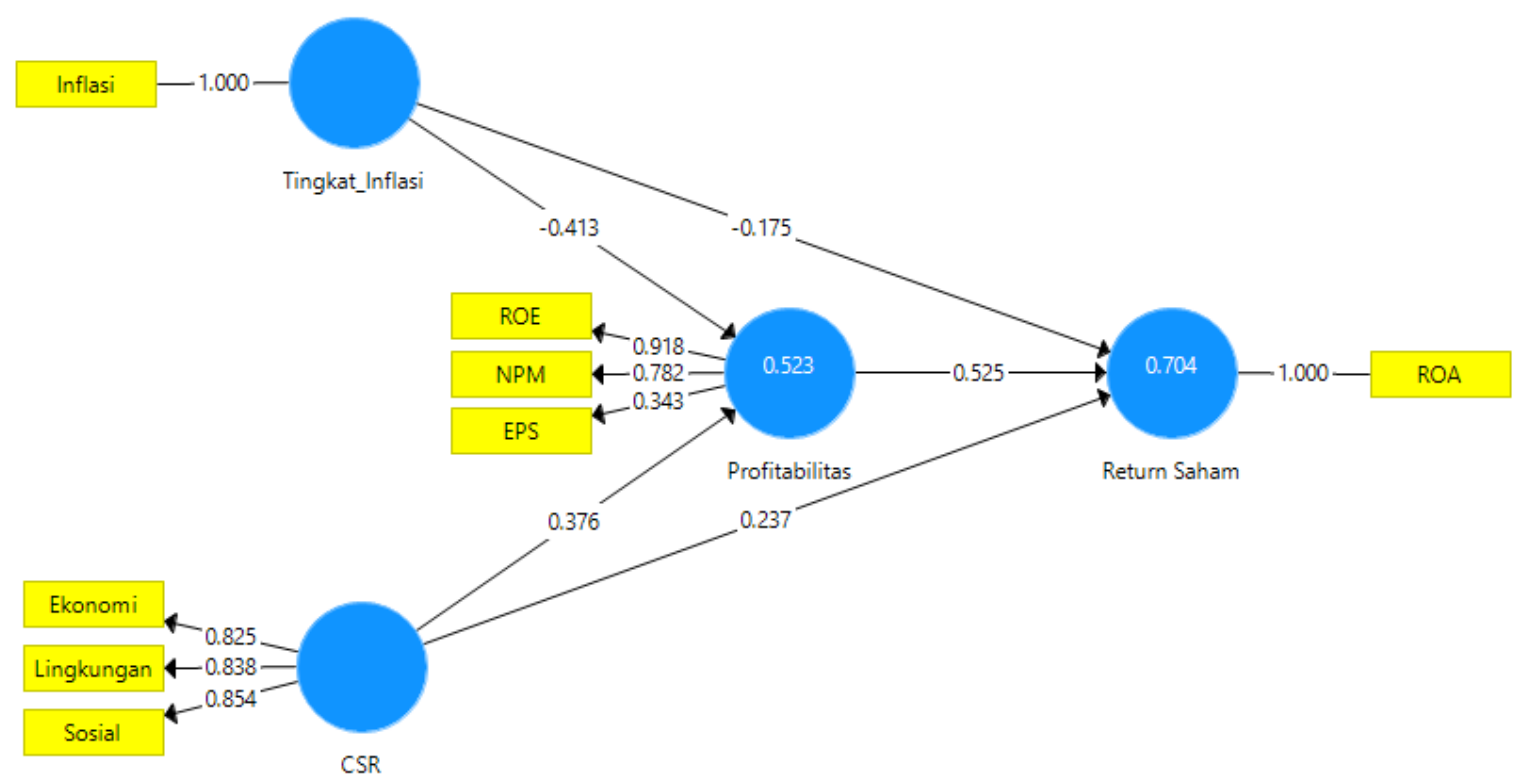

Figure 4. The build of the Outer Model

\subsection{Hypothesis evaluation}

Exogenous variables are checked for their effect on endogenous variables using significance checking. The evaluation parameters claim that there is a substantial impact of exogenous variables on endogenous variables whether the significance T-statistics T-table (1.96) or PValue significant alpha $5 \%$ or 0.05 . The meaning and model research findings are discussed in the following statistics and graphs. 


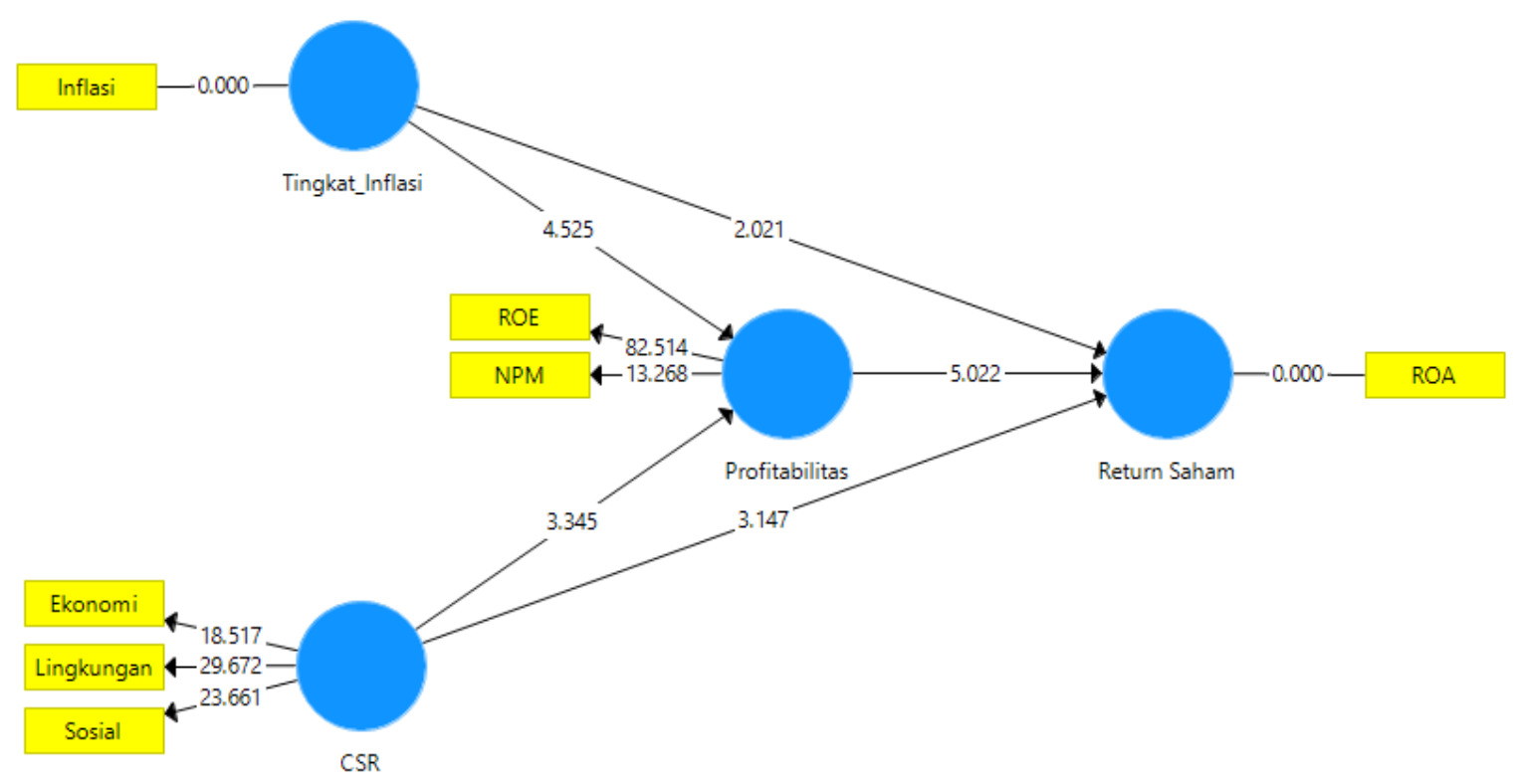

Figure 5. Inner Model construct

Table 3.

Hypothesis Testing Results

\begin{tabular}{clcccc}
\hline No. & Correlation between variables & $\begin{array}{c}\text { Original } \\
\text { Sample (O) }\end{array}$ & $\begin{array}{c}\text { T Statistics } \\
(\mid \mathbf{O} / \text { STDEV } \mid)\end{array}$ & P Values & Information \\
\hline 1 & Inflation Rate -> Stock Return & -0.167 & 2,021 & 0.044 & Significant \\
2 & Inflation Rate -> Profitability & $-0,428$ & 4,525 & 0.000 & Significant \\
3 & CSR -> Stock Return & 0.238 & 3,147 & 0.002 & Significant \\
4 & CSR -> Profitability & 0.366 & 3,345 & 0.001 & Significant \\
5 & Profitability -> Stock Return & 0.529 & 5,022 & 0.000 & Significant \\
\hline
\end{tabular}

4.3.1. Hypothesis 1: For the duration 2017-2019, the pace of inflation has a substantial influence on stock returns in the mining sector listed on the IDX.

The test Influence Inflation rate against stock returns in mining companies reported on the IDX for the period 2017 - 2019 produces a score T statistics $>1.96$ with a p-value of 0.05 , as seen in the table above. For the duration 2017-2019, it can be inferred that the pace of inflation has a substantial effect on stock returns in mining companies classified on the IDX. As a consequence, hypothesis 1 in this analysis is valid. The final coefficient is -0.167 (negative), meaning that As the inflation rate rises by $1 \%$, the stock return continues to fall by 0.167 percent. The outcomes of this report suggest that inflation has a major influence on stock returns. Where inflation increases, stock returns will decrease, and vice versa. If inflation decreases, the return on stock obtained for investors will increase. This study is supported by the results of research by Djayani Nurdin (1999) entitled Investment Risk in Property Shares on the Jakarta Stock Exchange with the result that inflation has a significant effect on the risk of investing in property stocks on the Jakarta Stock Exchange. 
4.3.2. Hypothesis 2: For the duration 2017-2019, the pace of inflation has a substantial influence on profitability in the mining sector mentioned on the IDX.

The measure Influence Inflation rate against profitability in mining companies classified on the IDX for the duration 2017 - 2019 produces a score T statistics $>1.96$ with a p-value of 0.05 , as seen in the table above. It can be inferred that the degree of inflation has a substantial effect on the profitability of mining companies listed on the IDX from 2017 to 2019. As a consequence, hypothesis 2 in this analysis is valid. The resultant coefficient is -0.428 (negative), implying that a $1 \%$ rise in inflation causes a 0.428 percent decline in profitability. The findings of this research show that inflation has a major impact on profitability. As a consequence, the findings of this study are compatible with those of Hidayati (2016), who noticed that inflation has a favorable and substantial influence on profitability.

\subsubsection{Hypothesis 3: For the period 2017 to 2019, CSR (Corporate Social Responsibility) had a substantial influence on stock returns in the mining sector reported on the IDX.}

The test Impact CSR (Corporate social responsibility) on stock returns in mining companies listed on the IDX for the duration 2017 - 2019 provides a score T statistics $>1.96$ with a p-value 0.05, as seen in the table above. For the duration 2017-2019, it can be inferred that CSR (Corporate Social Responsibility) has a substantial impact on stock returns in mining companies reported on the IDX. As a consequence, Hypothesis 3 is fulfilled in this review. The resulting coefficient is 0.238 (positive), implying that increasing CSR by one unit raises Stock Return by 0.238 percent. The findings of this research show that corporate social responsibility has a substantial impact on stock returns. This demonstrates that the more a business discloses on its corporate social obligation (CSR), the greater the effect on stock returns. The findings of this report CSR transparency has a major influence on equity returns, suggesting that investors accept CSR details while making investment decisions. Consistent with research by Kim, et al (2014) and Cheng and Yulius (2011) which show that CSR affects stock returns. This research is supported by the results of research from Prasetyo (2017), Gantino (2016), Putri (2014), Rosdwianti (2016) and Citraningrum (2014) which state that CSR disclosure has a significant effect on company ROA.

4.3.4. Hypothesis 4: For the period 2017-2019, corporate social responsibility has a substantial impact on profitability in the mining sector described on the IDX.

The test Influence CSR (Corporate social responsibility) on profitability in mining companies included on the IDX for the duration 2017 - 2019 produces a score T statistics $>1.96$ with a pvalue of 0.05 , as seen in the table above. For the duration 2017-2019, it can be inferred that CSR (Corporate Social Responsibility) has a substantial impact on profitability in mining companies classified on the IDX. As a result, Hypothesis 4 is fulfilled in this study. The resulting coefficient is 0.366 (positive), implying that raising the CSR by one unit increases profitability by 0.366 percent. According to the conclusions of this report, Corporate Social Responsibility has an effect on profitability. The findings of a recent study conducted by Feb Tri Wijayanti back up this argument, Sutaryo and Muhammad Agung Prabowo (2011). 


\subsubsection{Hypothesis 5: For the period 2017-2019, profitability has a substantial influence on stock returns in the mining sector described on the IDX.}

The test Impact Profitability on stock returns in mining companies mentioned on the IDX for the duration 2017 - 2019 provides a score T statistics $>1.96$ with a p-value of 0.05 , as seen in the table above. For the duration 2017-2019, it can be inferred that profitability has a substantial influence on stock returns in mining companies classified on the IDX. As a result, Hypothesis 5 is satisfied in this study. The resulting coefficient is 0.529 (positive), indicating a positive profitability. If the stock return is raised by $1 \%$, the stock return is increased by 0.529 percent. This study's findings suggest that profitability has a major influence on stock returns. The optimistic association contained in the study's findings suggests that as profitability (ROE) grows, so will stock returns. When it comes to consumer products firms, consumers recognize the importance of ROE when making investment choices. The findings of this analysis are backed up by studies by Wong Pik Har \& Ghafar (2015), Andansari et al. (2016), and Apriliani \& Hartini (2016), all of whom say that ROE has an effect on stock returns.

\section{Conclusion}

The following conclusions can be drawn in this analysis focused on the findings of data analysis on inflation and corporate social responsibility (CSR) on stock returns with profitability as an intervening vector for the Mining sector listed on the Indonesia Stock Exchange (IDX) for the duration 2017-2019. It can be shown, based on the model estimation performance, that:

1. For the 2017-2019 timeframe, inflation has an impact on the return of shares gained by shareholders of mining firms listed on the Indonesia Stock Exchange (IDX).

2. For the 2017-2019 timeframe, inflation has an impact on the earnings of shareholders of mining firms listed on the Indonesia Stock Exchange (IDX).

3. For the 2017-2019 timeframe, corporate social responsibility (CSR) has an impact on stock returns received by shareholders of mining firms listed on the Indonesia Stock Exchange (IDX).

4. For the 2017-2019 timeframe, corporate social responsibility (CSR) has an impact on the earnings of shareholders in mining firms listed on the Indonesia Stock Exchange (IDX).

5. The return on shares received by shareholders from mining enterprises listed on the Indonesia Stock Exchange (IDX) for the 2017-2019 timeframe is influenced by profitability.

\section{References}

Putra, A.A. Wela Yulia (2015). Pengaruh leverage, pertumbuhan penjualan dan ukuran perusahaan terhadap profitabilitas. Fakultas Ekonomi dan Bisnis Universitas Udayana (Unud), Bali. ISSN 2302-8912.

Aggarwal, Priyanka (2013). Impact of Corporate Governance on Corporate Financial Performance. IOSR Journal of Business and Management (IOSR-JBM). Vol 13 PP 01-05.

Agnes, Sawir (2009). Analisa Kinerja Keuangan dan Perencanaan keauangan Perusahaan. Jakarta: PT. Gramedia Pustaka Utama.

Ambarwati, Sri Dwi Ari (2010). Manajemen Keuangan Lanjut. Jogyakarta: Graha Ilmu 
Ang, Robert (1997). Buku Pintar Pasar Modal Indonesia, Edisi 1, Mediasoft Indonesia.

Angelia, Dessy dan Rosita Suryaningsih (2015). The Effect of Environmental Performance and Corporate Social Responsibility Disclosure Toward Financial Performance (Case Study to Manufacture, Infrastructure, and Service Companies That Listed at Indonesia Stock Exchange). Procedia Social and Bahvior Sciences. 211: 348-355.

Arista, Desy dan Astohar (2012). Analisis Faktor-Faktor yang Mempengaruhi Return Saham (Kasus pada Perusahaan Manufaktur yang Go Public di BEI periode tahun 2005 - 2009). Jurnal Ilmu Manajemen dan Akuntansi Terapan, Vol. 3, No. 1, Hal. 1 - 15.

Bambang Riyanto (2013). Dasar-Dasar Pembelanjaan Perusahaan. Edisi Keempat. BPFEYogyakarta. Yogyakarta.

Bambang, Riyanto (2010). Dasar-Dasar Pembelanjaan Perusahaan, (Edisi 4) BPFE. YOGYAKARTA.

Boediono (1994). Ekonomi Makro. Seri Sinopsis Pengantar Ilmu Ekonomi No. 2, Edisi ke-4, BPFE: Yogyakarta.

Brigham, Eugene.F., dan Joul F Houston (2010). Dasar-Dasar Manajemen Keuangan. Jakarta: Salemba Empat.

Christiawan, Yulius Jogi. Rafika Anggraini Putri (2014). The Effect of Profitability,Liquidity, and Leverage on Disclosure of Corporate Social Responsibility.

Christiawan, Yulius Jogi. Rafika Anggraini Putri (2014). "Pengaruh Profitabilitas, Likuiditas, dan Leverage Terhadap Pengungkapan Corporate Social Responsibility”.

Djohanputro, Bramantyo (2006). Prinsip-Prinsip Ekonomi Makro. Cet.I. Penerbit PPM: Jakarta

Fahmi, Irham dan Yovi Lavianti Hadi (2009). "Teori Portofolio dan Analisis Investasi”, Bandung: Alfabeta

Fahmi, Irham (2016). Pengantar Manajemen Keuangan. Bandung: ALFABETA, CV.

Fahmi, Irham (2015). Introduction to Financial Management Theory and Questions and Answers. Bandung: Alfabeta.

Hadi, Nor (2011). Corporate Social Responsibility. First Cet.Yogyakarta: Graha Ilmu.

Harahap, Sofyan Syafri. (2008). Bank dan lembaga keuangan lainnya. Jakarta: PT.Raja Grafindo Persada.

Harahap, Sofyan Syafri. (2009). Teori Kritis Laporan Keuangan. Jakarta: Bumi Aksara

Hardaningtyas, Ratna Tri \& Siswoyo, Bambang Banu. (2016. Pengaruh Kebijakan Deviden dan Corporate social responsibility (CSR) terhadap Return saham pada Perusahaan LQ 45 Periode 2015. Jurnal Pendidikan: Teori, Penelitian, dan Pengembangan.

Hartono Jogyanto (2013). Teori Portofolio dan Analisis Investasi, BPFE Yogyakarta, Edisi Kedelapan, Yogyakarta. 
Husnan, Suad. (2005). Dasar-Dasar Teori Portofolio dan Analisis Sekuritas. Edisi keempat. Yogyakarta: UPP AMD YKPN

Jogiyanto Hartono. (2010). Teori Portofolio Dan Analisis Investasi. Yogyakarta: BPFE.

Kasmir. (2012). Analisis Laporan Keuangan. Jakarta: PT. Raja Grafindo Persada.

Kasmir. (2008). Analisis Laporan Keuangan. Rajawali Pres. Jakarta.

Khairudin, \& Dewi, E. (2015). Effect of Disclosure Corporate social responsibility (CSR) to Profitability in Textile and Garment Industry Listed in Indonesia Stock Exchange in 20112013. Jurnal Akuntansi Dan Keuangan, 6(2), 20.

Kuncoro, Mudrajad (1998). Metode Kuantitatif Teori \& Aplikasi Unutk Bisnis \& Ekonomi. Yogyakarta: YKPN.

Manurung, D. T., Kusumah, W. R., Hapsari, D. W., \& Husnatarina, F. (2017). Effect of Corporate Social Responsibility Disclosure on Financial Performance. International Journal of Arts and Commerce, 6, 40 .

Nuryaman. (2013). The Effect of Corporate Social Responsibility Activities on Profitability and Stock Price (Studies on The Companies Listed on Indonesia Stock Exchange). 4th International Conference on Business and Economic Research (4th ICBER 2013) Proceeding: 756-769.

Samuelson, Paul A. and William D. Nordhaus, (2001). Macroeconomics. Seventeenth Edition. McGraw-Hill Higher Education.

Setyorini, Cristina Tri and Zaini Ishak. (2012). "Corporate Social and Environmental Disclosure: A Positive Accounting Theory, View Point". International Journal of Business and Social Science. Vol. 3. No.9. pp. 1- 13.

Simamora, Henry, (2000). Manajemen Pemasaran Internasional (jilid 1), Jakarta: Salemba Empat

Sufiana, Nina dan Ni Ketut Purnawati. (2012). Pengaruh Perputaran Kas, Perputaran Piutang dan Perputaran Persediaan Terhadap Profitabilitas. Jurnal. Bali: Universitas Udayana.

Sugiyono, (2009). Quantitative Research Methods, Qualitative and R \& D, Bandung: Alfabeta.

Suriyani and Sudiartha, (2018). The Effect of Interest Rate, Inflation and Exchange Rate on Share Returns in Indonesia Stock Exchange. E-Journal of Management of Udayana University, Vol. 7, No. 6, 2018: 3172-3200

Sutrisno. (2009). Manajemen Keuangan Teori, Konsep dan Aplikasi, Edisi Pertama, Cetakan Ketujuh, Penerbit Ekonisia, Yogyakarta

Syamsuddin, Lukman. (2009). Manajemen Keuangan Perusahaan Konsep Aplikasi dalam: Perencanaan, Pengawasan, dan Pengambilan Keputusan. Jakarta: PT. Raja Grafindo.

Toto Prihadi. (2008). Deteksi Cepat Kondisi Keuangan : 7 Analisis Rasio Keuangan. Cetakan 1. Jakarta: PPM. 
Wardani, M. K. P. W. (2015). Pengaruh Pengungkapan Corporate social responsibility Terhadap Profitabilitas Perusahaan (Studi Empiris pada Perusahaan yang Terdaftar di BEI tahun 2010-2012). Universitas Sanata Dharma.

Yusuf, Wibisono (2007). Membedah Konsep \& Aplikasi CSR (Corporate Social Responsibility), PT Gramedia, Jakarta. 